\title{
Analiza rozwiązań złożonych mostków termicznych pod względem udoskonalania ich parametrów cieplnych
}

\author{
Sylwia Kulczewska, Walery Jezierski
}

\author{
Zakład Podstaw Budownictwa i Fizyki Budowli, Wydziat Budownictwa i Inżynierii Środowiska, \\ PolitechnikaBiałostocka,e-mail: s.kulczewska@pb.edu.pl,w.jezierski@pb.edu.pl.
}

Streszczenie: Artykuł dotyczy analizy rozwiązań złożonych mostków termicznych, występujących w węzłach mocujących elewacji wentylowanych oraz sposobu ich uwzględniania w obliczeniach cieplnych. Na podstawie tej analizy wykryto szereg czynników, które mogą wpływać na parametry cieplne mostków termicznych, jednak nie są one odzwierciedlone we wzorach $\mathrm{z}$ aktualnych norm. W związku z tym należy szukać nowych podejść i zależności, które w sposób precyzyjny pozwolą określić parametry fizyko-techniczne podobnych węzłów mocujących.

Słowa kluczowe: mostki termiczne, złożone mostki termiczne, parametry cieplne przegród, efektywność energetyczna.

\section{Wprowadzenie}

Mostek termiczny to miejsce w przegrodzie budowalnej o znacznie wyższej wartości współczynnika przewodzenia ciepła w stosunku do jej pozostałej części. W miejscach występowania mostków dochodzi do wzmożonego i niekontrolowanego przenoszenia ciepła. Dodatkowo, przy różnicy temperatur na zewnątrz i wewnątrz budynku mamy do czynienia z miejscowym wychładzaniem przegrody, co może spowodować przy niskich temperaturach zewnętrznych spadek temperatury na powierzchni wewnętrznej ściany poniżej punktu rosy. Zjawisko to sprzyja wykraplaniu się kondensatu na powierzchni wewnętrznej ścian w budynkach oraz niesie ryzyko rozwoju pleśni i grzybów w dalszym etapie. Można więc z pewnością stwierdzić, że mostki termiczne mają negatywny wpływ zarówno na ochronę cieplną oraz stan wilgotnościowy przegród.

Mostki cieplne najczęściej występują w węzłach konstrukcyjnych a przyczyną ich powstawania są zazwyczaj błędy projektowe i wykonawcze. Należy pamiętać, że kiedy już powstaną, są one bardzo trudne do usunięcia. Dlatego warto zadbać o osłabienie ich negatywnego wpływu lub całkowitą eliminację już na etapie projektowania. Przy rozwiązywaniu tego problemu konieczne jest zastosowanie kształtowania materiałowego poszczególnych elementów składowych węzła tak, aby zredukować do minimum wpływ mostka na parametry cieplno-wilgotnościowe budynku.

W przypadku istniejącego obiektu znalezienie miejsc o wzmożonej ucieczce ciepła należy rozpocząć od analizy projektu budowlanego. Analiza ta jednak nie daje pewności, że podczas realizacji budynku nie pojawiły się mostki cieplne. Aby sprawdzić, czy one występują przeprowadza się badanie termowizyjne, które polega na wykonaniu za pomocą kamery termowizyjnej w pasmie promieniowania podczerwonego serii zdjęć (termogramów) elewacji budynku. Na termogramach przegród zewnętrznych, przy wykorzystaniu kolorów, oznaczane są miejsca charakteryzujące się różną temperaturą. Im temperatura w danym miejscu przegrody jest wyższa, tym większe straty ciepła. W przypadku występowania mostków termicznych mamy do czynienia z lokalnym wzrostem temperatury na 
powierzchni zewnętrznej przegrody [1]. Dzięki takiemu badaniu można znaleźć miejsca, w których występują mostki termiczne a następnie podjąć działania mające na celu osłabienie ich negatywnego wpływu na budynek. W przypadku mostków o prostej budowie działania te mogą okazać się dość łatwe. Problem zaczyna się w przypadku mostków o skomplikowanym układzie, ponieważ parametry cieplne przegrody zależą wówczas od wielu elementów tego mostka.

W zależności od ilości i właściwości elementów składowych danego mostka można określić stopień jego złożoności. Jako złożone mostki termiczne można uznać takie, które wykonane są z dużej liczby elementów składowych o bardzo zróżnicowanych wartościach współczynnika przewodzenia ciepła i przebijających na wylot warstwę termoizolacyjną przegrody.

Opracowanie podejścia do oszacowania parametrów takich mostków jest zagadnieniem aktualnym, między innymi ze względu na wprowadzanie coraz ostrzejszych wymagań dotyczących ochrony cieplnej budynków. Niewątpliwie minimalizacja lub całkowita likwidacja negatywnego wpływu mostków przyczyni się do poprawy efektywności energetycznej budynku. Biorąc pod uwagę problem dzisiejszego świata, którym jest nadmierne zużycie energii a tym samym zagrożenie wyczerpania surowców energetycznych, niezbędne jest dokonanie wszelkich możliwych działań, które przyczynią się do poprawy osłabionych miejsc w przegrodach budowlanych.

W niniejszym artykule przedstawiono analizę charakterystycznych oraz często spotykanych mostków termicznych o skomplikowanej konfiguracji i rozwiązaniach materiałowych, z wyszczególnieniem parametrów geometrycznych i fizyko-technicznych mogących stanowić czynniki istotne wpływające na parametry cieplne mostków termicznych.

\section{Przykłady złożonych mostków termicznych}

Złożonymi mostkami termicznymi można nazwać węzły mocujące w elewacjach wentylowanych. Podstawą tego rodzaju elewacji jest stelaż nośny zakotwiony w części konstrukcyjnej przegrody. Konstrukcja stelaża wraz z elementami mocującymi przebija na wylot warstwę izolacji termicznej ściany powodując powstanie mostka.

Mostek termiczny tego typu występuje na przykład w systemie mocowania elewacyjnego oferowanego przez firmę COPAL [2] (Rys.1). System ten wykorzystywany jest między innymi do montażu płyt włókno-cementowych, które znajdują duże uznanie u inwestorów i architektów dzięki możliwościom kreowania nowoczesnego wyglądu elewacji budynku oraz dobrym parametrom cieplno-wilgotnościowym [3].

Głównym elementem tego rozwiązania jest konstrukcja aluminiowa, która dzięki odpowiednim elementom mocującym zakotwiona jest w części nośnej przegrody. System składa się z konsoli pojedynczej i podwójnej COPAL, podkładki termoizolacyjnej, profili nośnych $\mathrm{T}$ oraz L, kotwy montażowej oraz łączników scalających poszczególne elementy podkonstrukcji. Przy zastosowaniu konsoli COPAL można uzyskać wysięg elewacji w stosunku do ściany budynku od $100 \mathrm{~mm}$ do $220 \mathrm{~mm}$. Płyty włókniste mocowane są do rusztu zazwyczaj za pomocą nitów. Zastosowanie odpowiednich elementów i akcesoriów systemu pozwala na elastyczne konstruowanie elewacji wentylowanych, które coraz częściej pojawiają się w budownictwie [2].

Innym przykładem występowania złożonego mostka termicznego może być węzeł mocujący systemu fasad Vetisol Cristo [4] (rys. 2.) oferowanego przez firmę Vetisol. System ten oparty jest o pionową konstrukcję szkieletową wykonaną z metalowych kształtowników, do których mocowana jest sieć poziomych listew aluminiowych. 


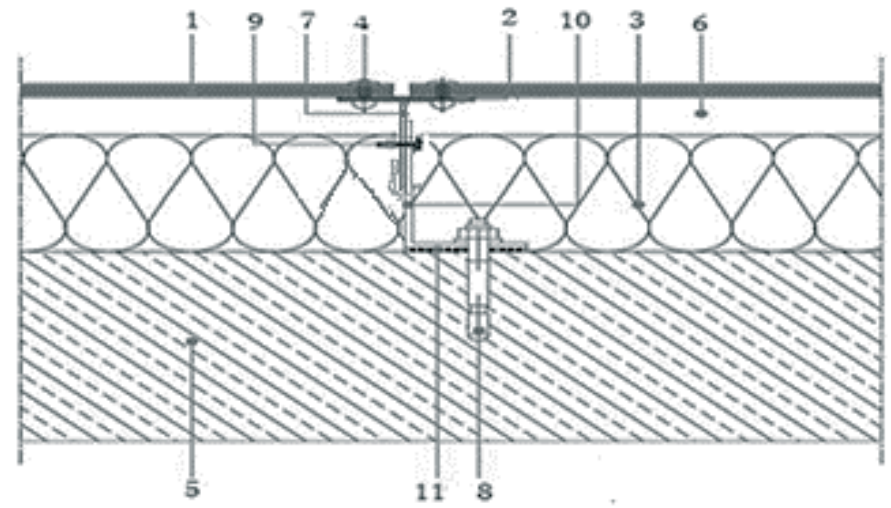

Rys. 1. Konstrukcja wentylowanej elewacji z pionowym układem listew mocujących. 1 - płyta włóknistocementowa gr. 8 mm, 2 - taśma EPDM, 3 - izolacja termiczna z welonem, 4 - nit mocujący, 5 - ściana konstrukcyjna, 6 - szczelina wentylacyjna $(20-50 \mathrm{~mm}), 7$ - element rusztu, podkonstrukcja aluminiowa, np. teownik, 8 - kotwa mocująca, 9 - wkręt, 10 - element rusztu, konsola aluminiowa, 11 podkładka termoizolacyjna [3]

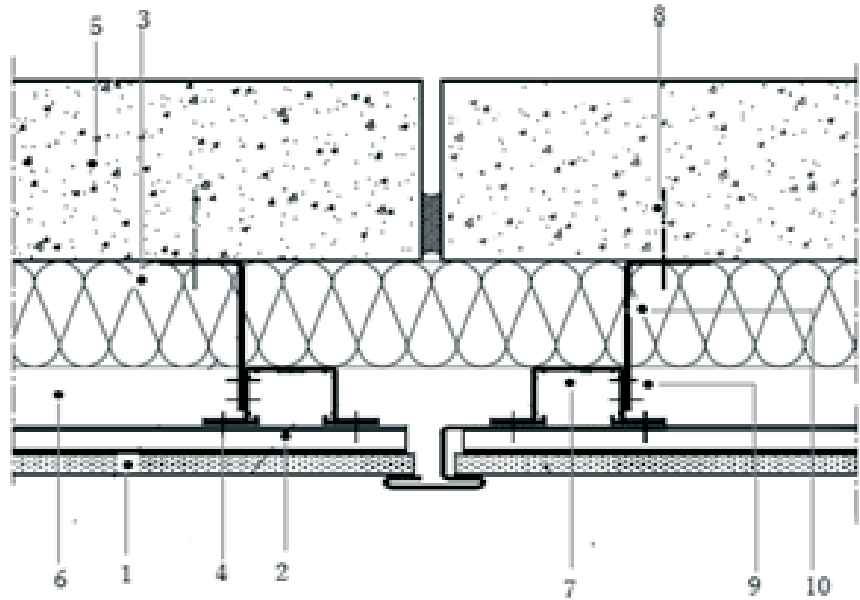

Rys. 2. Konstrukcja wentylowanej elewacji Vetisol z poziomym układem listew mocujących. 1 - płyta VETISOL CRISTO, 2 - listwa montażowa, 3 - izolacja termiczna z welonem, 4 - śruba mocująca, 5 ściana konstrukcyjna, 6 - szczelina wentylacyjna, 7 - element rusztu (kapelusz), 8 - kotwa mocująca, 9 - wkręt i śruby blokujące, 10 - element rusztu, zaczep kątowy [4]

W systemie tym wykorzystywane są firmowe okładziny elewacyjne (grubości $14 \mathrm{~mm}$ lub $20 \mathrm{~mm}$ ) wykonane z kruszywa marmurowego i żywicy poliestrowej. Okładziny mocowane są za pomocą odpowiednich śrub do poziomych listew montażowych szkieletu konstrukcyjnego. Pionowe kształtowniki stalowe, które stanowią główny element elewacji otrzymywane są metodą gięcia stali ocynkowanej ogniskowo. Elementy te mają na ogół przekrój w kształcie kapelusza. Główne rygle pionowe mocowane są na zaczepach kątowych przy pomocy wkrętów i dwóch śrub blokujących [4].

Kolejnym przykładem złożonego mostka termicznego może być węzeł mocujący systemu fasad Vespol Fix opracowany przez firmę Vespol [5], którego schemat przedstawiono na rysunku 3. 


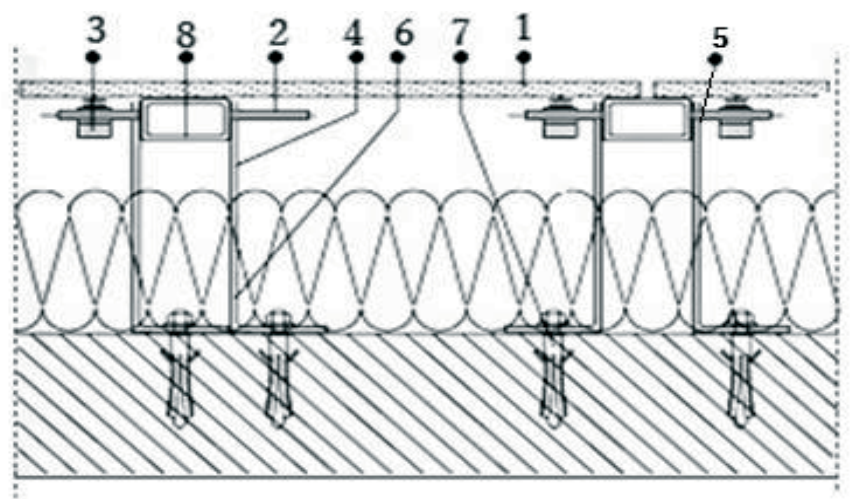

Rys. 3. Konstrukcja wentylowanej elewacji Vespol FIX z zamkniętymi profilami mocującymi. 1 - płyta elewacyjna, 2 - trzpień, 3 - łącznik płyty elewacyjnej, 4 - przedłużenie rektyfikacyjne, 5 - śruba samowkrętna, 6 - kotwa podstawowa nośna, 7 - kołek rozporowy, 8 - profil nośny, 9 - izolacja, 10 pustka powietrzna [5]

Podstawowym elementem tego systemu jest ruszt nośny wykonany z zamkniętych profili aluminiowych o rozmiarach 40/20, 50/30, 60/20 i stalowych nierdzewnych sworzni o dł. $150 \mathrm{~mm}$ i średnicy $6 \mathrm{~mm}$ służących do zawieszenia okładziny. Okładziny wykonywane są głównie z kamieni naturalnych (granit, marmur) lub sztucznych (gres, laminat). Rozmieszczenie sworzni oraz profili rusztu jest zależne od rozmiarów okładziny. Elementy rusztu przymocowane są do podłoża (ściany) poprzez aluminiowe kotwy [5].

Można zauważyć, że wszystkie przedstawione węzły mocujące elewacji wentylowanych charakteryzują się złożoną budową. W każdym systemie została również przebita na wylot przez stelaż nośny warstwa termoizolacyjna, co powoduje powstaje niejednorodności zarówno konstrukcyjnej jak i cieplnej danej przegrody.

\section{Uwzględnienie mostków termicznych w obliczeniach cieplnych}

Mostki termiczne należy oszacować w aspekcie ich wpływu na stan termiczny przegrody. W tym celu należy podać rozkład temperatur w obszarze jego występowania, określić temperatury na powierzchni wewnętrznej przegrody tworzącej mostek oraz zbadać straty ciepła przez mostek. Należy pamiętać, że straty ciepła spowodowane istnieniem w złączach mostków termicznych mogą stanowić ważną część bilansu energetycznego i nie należy ich pomijać przy ocenie efektywności energetycznej budynku [6].

Podstawowym parametrem charakteryzującym przegrodę jest wartość współczynnika przenikania ciepła $U\left[\mathrm{~W} /\left(\mathrm{m}^{2} \mathrm{~K}\right)\right]$. Obliczeniowe wyznaczenie tego parametru w praktyce wymaga pewnej korekty poprzez uwzględnienie poprawek. W przypadku złożonych mostków termicznych występujących w elewacjach wentylowanych istotne znaczenie ma wpływ łączników mechanicznych. Wg normy PN-EN ISO 6946:2008 [7] uwzględnienie tego rodzaju łączników w sposób uproszczony można określić na podstawie wzoru:

$$
\Delta U_{f}=\alpha \frac{\lambda_{f} A_{f} n_{f}}{d_{o}}\left(\frac{R_{1}}{R_{T, h}}\right), \quad\left[\mathrm{W} /\left(\mathrm{m}^{2} \mathrm{~K}\right)\right]
$$

gdzie: $\alpha=0,8$ - jeżeli łącznik całkowicie przebija warstwę izolacji; $\alpha=0,8 \mathrm{~d}_{1} / \mathrm{d}_{0}-\mathrm{w}$ przypadku łącznika wpuszczonego w izolację, czyli przebijającego izolację na części grubości tej warstwy; $\lambda_{f}$ - współczynnik przewodzenia cieplna materiału łącznika $[\mathrm{W} /(\mathrm{mK})] ; n_{f}-$ liczba 
łączników na $1 \mathrm{~m}^{2} ; A_{f}$ - pole przekroju poprzecznego jednego łącznika $\left[\mathrm{m}^{2}\right] ; d_{o}-$ grubość warstwy izolacji cieplnej przebitej przez łącznik $[\mathrm{m}] ; d_{1}$ - długość łącznika przechodzącego przez izolację cieplną $[\mathrm{m}] ; R_{1}$ - opór cieplny warstwy izolacji cieplnej przebitej przez łącznik $\left[\mathrm{m}^{2} \mathrm{~K} / \mathrm{W}\right] ; R_{T, h}$ - opór cieplny przegrody z pominięciem wpływu mostków cieplnych $\left[\mathrm{m}^{2} \mathrm{~K} / \mathrm{W}\right]$.

Uwzględnienie złożonych mostków termicznych na podstawie tego wzoru wprowadza pewne niedokładności. W przedstawionych mostkach w elewacjach wentylowanych warstwa termoizolacji w każdym przypadku jest przebita całkowicie przez łącznik, który następnie zakotwiony jest w ścianie nośnej. Przyjęcie parametru $\alpha=0,8$ nie uwzględnia zmian średnicy użytego łącznika, która niewątpliwe wpływa na parametry mostka. Oprócz kotwy w przedstawionych mostkach termicznych występują elementy dodatkowe, które również przebijają warstwę termoizolacji a tym samym pogorszają parametry węzła. Przy dokładnym wyznaczaniu parametrów mostka należałoby określić głębokość zakotwienia łącznika w elemencie konstrukcyjnym, która zależy między innymi od wytrzymałości materiału ściany oraz długości kołka. W zależności (1) nie podano także współczynnika przewodzenia ciepła innych materiałów elementów węzłów mocujących oprócz łącznika. Dodatkowo wzór 1 nie uwzględnia konfiguracji elementów całego węzła i ich parametrów geometrycznych.

Tak więc można zauważyć, że uproszczona metoda opisująca wpływu mostków wg normy [7] jest niewystarczająca aby określić wpływ parametrów wszystkich elementów mocujących. Z pewnością takie oszacowanie wpływu łączników na parametry mostka obarczone jest dość dużym błędem.

Bardziej dokładne podejście obliczeniowe przedstawione jest w normie PN-EN ISO 10211 [8]. W celu pełnej oceny wpływu mostka na stan cieplno-wilgotnościowy przegrody należy wyznaczyć jego podstawowe, charakterystyczne parametry. Indywidualną cechą liniowego mostka cieplnego jest wartość współczynnika $\psi$. Dla niektórych typów mostków parametr ten jest podany w różnych katalogach lub normie PN-EN 14683 [9]. Jednak wartości $\psi$ określone $\mathrm{w}$ ten sposób są mało precyzyjne, gdyż katalogi i normy podają jedynie wartości orientacyjne. Lepszą metodą określenia parametrów mostka są metody komputerowe. W przypadku mostków punktowych (typu 3D), które występują w węzłach izolacji wentylowanych, wielkością opisującą ich wpływ na całkowity strumień ciepła jest punktowy współczynnik przenikania ciepła $\chi$. Określany jest zazwyczaj przy wykorzystaniu obliczeń numerycznych lub analiz komputerowych, indywidualnie dla każdego mostka [6]. Wartość $\chi$ na podstawie normy [8] wyznacza się wg zależności:

$$
\chi=L_{3 d}-\sum_{j=1}^{N_{j}} \psi_{j} \cdot l_{j}-\sum_{i=1}^{N_{i}} \mathrm{U}_{i} \cdot A_{i}, \quad[\mathrm{~W} / \mathrm{K}]
$$

gdzie: $L_{3 d}=L-$ strumień ciepła płynący przez badane złącze $3 \mathrm{D}[\mathrm{W} / \mathrm{K}] ; \psi_{j}-$ liniowy współczynnik przenikania ciepła j-tej płaskiej gałęzi trójwymiarowego złącza $[\mathrm{W} /(\mathrm{m} \cdot \mathrm{K})]$; $l_{j}$ - długość, do której stosuje się wartość $\psi_{j},[\mathrm{~m}] ; U_{i}$ - współczynnik jednowymiarowego przenikania ciepła oddzielające dwa równoważne środowiska $\left[\mathrm{W} /\left(\mathrm{m}^{2} \cdot \mathrm{K}\right)\right] ; A_{i}$ - powierzchnia, do której się stosuje wartość $U_{i},\left[\mathrm{~m}^{2}\right] ; N_{j}$ - liczba liniowych współczynników przenikania ciepła w złączu; $N_{i}$ - liczba współczynników przenikania ciepła.

Obliczenia w tej metodzie wykonywane są głównie przy wykorzystaniu metod komputerowych z uwzględnieniem zaleceń zawartych w normie [8]. Przy projektowaniu należy odpowiednio określić granice geometryczne i podziały modelu, cieplne warunki brzegowe oraz wartości parametrów cieplnych i zależności, z których należy korzystać przy ocenie całkowitych strat ciepła w budynku. 
W literaturze przedmiotu [10] można znaleźć porównanie dokładnych metod uwzględnienia punktowych mostków termicznych [8] za pomocą modelowania komputerowego z metodami uproszczonymi [7]. Z przeprowadzonych przez autorów obliczeń wynika, że wpływ punktowych mostków termicznych związanych z łącznikami mechanicznymi na całkowitą wartość współczynnika przenikania ciepła U przegrody nie powinien być pomijany zarówno na etapie projektowania jak i przy analizach izolacyjności cieplnej. Otrzymane wyniki za pomocą metod komputerowych z pewnością są dużo dokładniejsze niż w metodzie uproszczonej, jednak to podejście jest pracochłonne i zajmuje bardzo dużo czasu. Dodatkowo wymaga od użytkownika dużej wiedzy, umiejętności obsługi i dostępności programu komputerowego. W każdym razie nie ma pewności, że mostek zostanie odpowiednio zamodelowany, tak aby program mógł uwzględnić wszystkie elementy składowe węzła, które wpływają na jego parametry cieplne.

\section{Określenie czynników, które mogą wpływać na parametry cieplne budynku}

Na przykładzie trzech mostków określono czynniki, które mogą wpływać na całkowitą wartość współczynnika przenikania ciepła mostka i które z puntu widzenia autorów należy uwzględniać w obliczeniach cieplnych. Zestaw tych czynników został określony po analizie rozwiązań wybranych mostków termicznych. Jak okazało się w analizowanych węzłach wykryto aż 16 możliwych czynników. Ich wartości zestawiono w tabeli nr1.

Tabela 1. Badane czynniki trzech typów złożonych mostków termicznych

\begin{tabular}{|c|c|c|c|c|}
\hline \multirow{2}{*}{$\begin{array}{c}\mathrm{Nr} \\
\text { czynnika }\end{array}$} & \multirow{2}{*}{ Nazwa czynnika } & \multicolumn{3}{|c|}{ Wartości: } \\
\hline & & Mostek 1 & Mostek 2 & Mostek 3 \\
\hline \multicolumn{5}{|c|}{ Panel elewacyjny } \\
\hline 1 & Współczynnik przewodzenia ciepła, W/(m·K) & 0,3 & 0,25 & 0,20 \\
\hline 2 & Grubość, $\mathrm{m}$ & 0,008 & 0,014 & 0,02 \\
\hline \multicolumn{5}{|c|}{ Wentylowana pustka powietrzna } \\
\hline 3 & Wymiar charakterystyczny, $\mathrm{m}$ & 0,02 & 0,03 & 0,03 \\
\hline \multicolumn{5}{|c|}{ Izolacja termiczna } \\
\hline 4 & Współczynnik przewodzenia ciepła, W/(m·K) & 0,040 & 0,40 & 0,40 \\
\hline 5 & Grubość, m & 0,15 & 0,15 & 0,15 \\
\hline \multicolumn{5}{|c|}{ Konstrukcyjna warstwa ściany } \\
\hline 6 & Współczynnik przewodzenia ciepła, W/(m·K) & 0,33 & 0,33 & 0,33 \\
\hline 7 & Grubość, m & 0,25 & 0,25 & 0,25 \\
\hline \multicolumn{5}{|c|}{ Stelaż nośny } \\
\hline 8 & Współczynnik przewodzenia ciepła, $\mathrm{W} /(\mathrm{m} \cdot \mathrm{K})$ & 200 & 200 & 200 \\
\hline 9 & Grubość, $m$ & 0,0015 & 0,0015 & 0,0015 \\
\hline 10 & Wymiary podstawy wspornika mocującego, $\mathrm{m}$ & $0,04 \times 0,04$ & $0,05 \times 0,06$ & $0,04 \times 0,02$ \\
\hline \multicolumn{5}{|c|}{ Przektadka izolacyjna } \\
\hline 11 & Współczynnik przewodzenia ciepła, $\mathrm{W} /(\mathrm{m} \cdot \mathrm{K})$ & 0,04 & 0,04 & 0,04 \\
\hline 12 & Grubość, m & 0,00 & 0,00 & 0,00 \\
\hline \multicolumn{5}{|c|}{ Kotek rozporowy } \\
\hline 13 & Średnica, $\mathrm{m}$ & 0,008 & 0,0055 & 0006 \\
\hline 14 & Głębokość zakotwienia, $\mathrm{m}$ & 0,05 & 0,06 & 0,05 \\
\hline 15 & Rozstaw kołków, m & 0,40 & 0,40 & 0,40 \\
\hline 16 & Współczynnik przewodzenia ciepła, W/(m·K) & 58 & 58 & 58 \\
\hline
\end{tabular}

Jak widać z tabeli 1 podane czynniki charakteryzują właściwości cieplne i techniczne materiałów oraz geometryczne cechy elementów tworzących węzeł mocujący. Na podsta- 
wie tych danych dokonywane będą dalsze rozważania w celu określenia spośród zaproponowanych czynników istotnych i nieistotnych dla parametrów cieplnych całego mostka.

\section{Podsumowanie}

Wymienione metody normowe pod względem ich zastosowania do oceny wpływu złożonych mostków termicznych na parametry cieplne przegrody nie są doskonałe. $\mathrm{Z}$ jednej strony uwzględniają one małą ilość czynników wpływających na właściwości cieplne przegrody. Z drugiej strony przy zastosowaniu modelowania komputerowego wymagają one dużych nakładów pracy, czasu oraz odpowiednich umiejętności użytkownika. Stopień dokładności opisanych metod może być sprawdzony eksperymentalnie lub za pomocą modelu pól temperaturowych z zastosowaniem współczesnych programów komputerowych 2D i 3D do analizy mostków punktowych. Jednak przy zachowaniu wysokiej dokładności obliczeń wymienionych metod nie dają one możliwości przeprowadzenia pełnej optymalizacji parametrów elementów składowych mostków oraz wykonania kształtowania materiałowego elementów pod kątem obniżenia wpływu mostków na pole temperaturowe przegrody. Analizy te będą przedmiotem dalszych rozważań naukowych autorów.

\section{Literatura}

1. Węglarz A., Sposoby wykrywania mostków termicznych. http://obudowaniu.pl/sposoby_wykrywania_mostkow_cieplnych.html [data dostępu 20.01.2016]

2. Systemy elewacyjne. Podkonstrukcje aluminiowe pod elewacje wentylowane; Ptyty elewacyjne. www.copal.com.pl [data dostępu 03.03.2016].

3. Schabowicz K., Szymków M. Elewacje wentylowane z płyt włóknisto-cementowych w ujęciu prawnym. Izolacje 9 (2015) 60-65.

4. Fasady VETISOL. Dokumentacja on-line, www.vetisol.pl [data dostępu 03.03.2016].

5. $\quad$ Systemy fasad Vespol. www.vespol.com.pl [data dostępu 03.03.2016].

6. Dylla A. Fizyka cieplna budowli w praktyce. PWN, Warszawa 2015, s.120-170.

7. PN-EN ISO 6946:2008, Komponenty budowlane $i$ elementy budynku. Opór cieplny $i$ współczynnik przenikania ciepła. Metoda obliczania.

8. PN-EN ISO 10211:2007, Mostki cieplne w budynkach. Strumienie ciepła i temperatury powierzchni. Obliczenia szczegółowe.

9. PN-EN ISO 14683:2008, Mostki cieplne w budynkach. Liniowy wspótczynnik przenikania ciepta. Metody uproszczone $i$ wartości orientacyjne.

10. Steidl T., Krause P. Punktowe mostki cieplne na etapie projektowania i oceny energetycznej budynków ogrzewanych. Materiały Budowlane 1 (2012) 57-62. 


\title{
The analysis of complex thermal bridges solutions in terms of improving their thermal parameters
}

\author{
Sylwia Kulczewska, Walery Jezierski \\ Department of Basic Building Construction and Building Physics, \\ Faculty of Civil and Environmental Engineering, Bialystok University of Technology, \\ e-mail:s.kulczewska@pb.edu.pl,w.jezierski@pb.edu.pl
}

\begin{abstract}
The article presents the analysis of complex thermal bridges solutions which occur in the fixing nodes of ventilated facade and the way of taking into consideration them in thermal calculations. On the basis of this analysis, a number of factors which may affect the thermal parameters of thermal bridges were detected. However they are not reflected in the formulas specified in current standards. Therefore, new approaches and correlations, that will precisely determine the physico-technical parameters of similar fixing nodes, should be looked for.
\end{abstract}

Keywords: thermal bridges, complex thermal bridges, thermal parameters of partitions, energy efficiency. 